\title{
Computer Vision for Supporting Visually Impaired People: A Systematic Review
}

\author{
Evania Joycelin Anthony ${ }^{1 *}$, Regina Anastasia Kusnadi ${ }^{2}$ \\ ${ }^{1,2}$ Computer Science Department, School of Computer Science, \\ Bina Nusantara University, \\ Jakarta, Indonesia 11480 \\ evania.anthony@binus.ac.id; regina.kusnadi@binus.ac.id \\ *Correspondence: evania.anthony@binus.ac.id
}

\begin{abstract}
Globally around the world in 2010, the number of people of all ages visually impaired is estimated to be 285 million, of whom 39 million are blind according to the study of World Health Organization (Global Data on Visual Impairments, 2010). Visual impairment has a significant impact on individuals' quality of life, including their ability to work and to develop personal relationships. Almost half (48\%) of the visually impaired feel "moderately" or "completely" cut off from people and things around them (Hakobyan, Lumsden, O'Sullivan, \& Bartlett, 2013). We believe that technology has the potential to enhance individuals' ability to participate fully in societal activities and to live independently. So, in this paper we focused to presents a comprehensive literature review about different algorithms of computer vision for supporting blind/vision impaired people, different devices used and the supported tasks. From the 13 eligible papers, we found positive effects of the use of computer vision for supporting visually impaired people. These effects included: the detection of obstacles, objects, door and text, traffic lights, sign detections and navigation. But the biggest challenge for developers now is to increase the speed of time and improve its accuracy, and we expect the future will have a complete package or solution where blind or vision impaired people will get all the solution together (i.e., map, indoor-outdoor navigation, object recognition, obstacle recognition, person recognition, human crowd behavior, crowd human counting, study/reading, entertainment etc.) in one software and in hand-held devices like android or any handy devices.
\end{abstract}

Keywords: Visually Impaired People (VIP); Computer Vision $(\mathrm{CV})$.

\section{INTRODUCTION}

Globally around the world, in 2010, the number of people of all ages visually impaired is estimated to be 285 million, of whom 39 million are blind, according to the study of World Health Organization (Global Data on Visual Impairments, 2010).

Regrettably, this percentage is expected to increase in the coming decades. Visual impairment has a significant impact on individuals' quality of life, including their ability to work and develop personal relationships. Almost half $(48 \%)$ of the visually impaired feel "moderately" or "completely" cut off from people and things around them (Hakobyan, Lumsden, O’Sullivan, \& Bartlett, 2013). Visual loss inevitably leads to impaired ability to access information and perform everyday tasks. In today's knowledgeintensive society, information access is increasingly crucial, not just for performing daily activities but also for engaging in education and employment. Also, even the simple tasks around the home can be hazardous if our vision is deteriorating. It's critical for visually impaired people to detect and recognize objects around them, especially in a new environment.

Computer vision is the science that gives the capability to computers to sense visually like humans. Computer vision is concerned with methods for acquiring, processing, analyzing, and of useful information from a single image or a sequence of images. It provides features to see and recognize objects like humans that are very helpful for impaired people (Shapiro \& Stockman, 2001). We are very interested in computer vision to support a better quality of life for individuals with disabilities, including visual impairment. We realize and believe that technology can enhance individuals' ability to participate fully in societal 
activities and live independently.

Many technologies in computer vision have been developed to assist people who are blind or visually impaired. This paper focused on presenting a systematic literature review about different algorithms, devices, and supported computer vision tasks for supporting visionimpaired people.

\section{METHODS}

A systematic approach for reviewing this literature is chosen. A systematic literature review is a means of identifying, evaluating, and interpreting all available research relevant to a particular research question, or topic area, or phenomenon of interest. Individual studies contributing to a systematic review are called primary studies; a systematic review is a form a secondary study (Kitchenham, 2004).

\subsection{Research Questions}

The research questions (RQ) were specified to keep the review focused. They were designed with the Population, Intervention, Comparison, Outcomes, and Context (PICOC) criteria (Kitchenham, 2004). Table 1 shows the (PICOC) structure of the research questions.

Table 1. Summary of PICOC

\begin{tabular}{cc}
\hline & Summary of PICOC \\
\hline Population & Computer Vision, Systems \\
\hline Intervention & Interface, approach, technology, supported tasks \\
\hline Comparison & - \\
\hline Outcomes & $\begin{array}{c}\text { Approach in CV used, technology and interface } \\
\text { used, covered supported tasks }\end{array}$ \\
\hline Context & Visually Impaired \\
\hline
\end{tabular}

The research questions and motivation addressed by this literature review are shown in Table 2.

Table 2. Research Questions

\begin{tabular}{ccc}
\hline ID & Research Question & Motivation \\
\hline RQ1 & $\begin{array}{c}\text { What kind of } \\
\text { algorithm in CV are } \\
\text { proposed? }\end{array}$ & $\begin{array}{c}\text { Identify the algorithm in } \\
\text { CV used in the systems for } \\
\text { Supporting VI }\end{array}$ \\
\hline RQ2 & $\begin{array}{c}\text { What kind of devices } \\
\text { are used? }\end{array}$ & $\begin{array}{c}\text { Identify the devices used in } \\
\text { the systems for supporting VI }\end{array}$ \\
\hline RQ3 & What are the supported & $\begin{array}{c}\text { Identify the supported tasks } \\
\text { tasks? }\end{array}$
\end{tabular}

\subsection{Study Selection}

The inclusion and exclusion criteria were used for selecting the primary studies. These criteria are shown in Table 3 below.

Table 3. Inclusion and Exclusion Criteria

\begin{tabular}{cc}
\hline Inclusion Criteria & Exclusion Criteria \\
\hline $\begin{array}{c}\text { Focused on approach in CV } \\
\text { for VI }\end{array}$ & $\begin{array}{c}\text { Studies not written in } \\
\text { English }\end{array}$ \\
\hline $\begin{array}{c}\text { Focused on the supported tasks } \\
\text { for visually impaired }\end{array}$ & $\begin{array}{c}\text { The outcomes of the articles } \\
\text { were not related to VI people }\end{array}$ \\
\hline
\end{tabular}

\subsection{Identification of Papers}

Included papers were published between 2016 and 2020. There were three elements to our searches: Keyword searching using the search engines: google scholar, an issue-by-issue manual reading of paper titles in relevant journals and conferences, and the identification of papers using references from included studies. A total of 45 papers were screened, and from that, 13 papers were selected.

\subsection{Data Extraction and Synthesis}

The selected primary studies are extracted to collect the data that contribute to addressing the research questions concerned in this review. The properties were identified through the research questions and used to answer the research questions shown in Table 4 . The data extraction is performed in an iterative manner.

Table 4. Data Extraction Properties Mapped to RQ

\begin{tabular}{cc}
\hline Property & RQ \\
\hline CV Algorithm & RQ1 \\
\hline Devices & RQ2 \\
\hline Supported Task & RQ3 \\
\hline
\end{tabular}

The data extracted in this review is qualitative data the narrative synthesis method was used.

\section{RESULT AND DISCUSSION}

In this review we aim to answer the research questions conducted, all the research question will be described one by one. But all the summaries can be seen in appendix Table 5.

\subsection{Proposed Algorithm in CV Used}

There are several techniques used to create $\mathrm{CV}$ systems for supporting VIP. In our review, we found six techniques. Those are edge detection, object and obstacle detection, image classification, image segmentation, character recognition, and feature extraction.

For Edge detection, we found two algorithms methods; canny edge detector that is used to detect doors (Sivan \& Darsan, 2016) and line segment detector, which is also used to detect doors with an accuracy rate of up to $93.2 \%$ for the ImageNet dataset (Talebi \& Vafaei, 2018). For objects and obstacle detection, we found three algorithms; first is CNN to recognize the color and sign of traffic got mAP of $96 \% \%$ (Li, Cui, Rizzo, Wong, \& Fang, 2020); in another research, CNN is also used to detect objects, but not accurate for multi objects in one scene, so they implemented RCNN (Balasuriya, Lokuhettiarachchi, Ranasinghe, Shiwantha, \& Jayawardena, 2017), second is YOLOv1 used to detect objects and obstacles and the detection rate is up to $89 \%$ for all kind of obstacles (Mocanu, Tapu, \& Zaharia, 2017), and third is YOLOv3 also used to detect objects, and the mAP is $73.19 \%$ (Afif, Ayachi, Pissaloux, Said, \& Atri, 2020), and in the other research the accuracy rate is up to 95.19\% (Joshi, Yadav, Dutta, \& Travieso-Gonzalez, 2020) and 92\% (Mahmud, Sourave, Islam, Lin, \& Kim, 2020). For image classification, we found two algorithms; the first is KNN to match the descriptor extracted (Elmannai \& 
Elleithy, 2018) and SVM to produce a category label for a scene (Zientara, et al., Feb. 2017). For Image segmentation, we found two algorithms as well: K-Means clustering to cluster $\mathrm{n}$ extracted points of a particular frame (Elmannai \& Elleithy, 2018) and FRRN (Duh, Sung, Chiang, Chang, $\&$ Chen, 2020). For character recognition, we only found optical character recognition (OCR) in three studies, where both studies show high accuracy results (Jiang, Gonnot, Yi, \& Saniie, 14-17 May 2017) (Sivan \& Darsan, 2016) (Joshi, Yadav, Dutta, \& Travieso-Gonzalez, 2020) and feature extraction using BRISK (Sivan \& Darsan, 2016); SURF (Dahiya, Issac, Dutta, Říha, \& Kříž, 4-6 July 2018) (Mahmud, Sourave, Islam, Lin, \& Kim, 2020) (Zientara, et al., Feb. 2017) and ORB (Duh, Sung, Chiang, Chang, \& Chen, 2020) (Elmannai \& Elleithy, 2018). The summary can be seen in appendix Table 6 .

\subsection{Devices used}

There are many types of equipment as well that were used to build CV systems or applications for supporting VIP. Some of the research are still in the software or application development stage, but other research has reached the prototype development stage. Because there are different stages of research, the tools used are also quite diverse. Studies that proposed a wearable device usually use single board computer, but in a study the researcher use ultrabook laptop to be carried in a backpack (Mocanu, Tapu, \& Zaharia, 2017), another study also use robot to assist VIP (Mahmud, Sourave, Islam, Lin, \& Kim, 2020).

For camera use, there are only two studies that use depth cameras. The depth camera used is the Zed Camera (Li, Cui, Rizzo, Wong, \& Fang, 2020), however, in this study the researcher did not focus on the depth of the information because it would be used in further studies and Astra S Camera (Mahmud, Sourave, Islam, Lin, \& Kim, 2020) which was used for path planning. Another researcher used smart glass camera for assisting VIP when shopping (Zientara, et al., Feb. 2017). The complete summary can be seen in appendix Table 7.

\subsection{Supported Tasks}

It's quite rare for researchers to include all the features in one project at once. From 13 eligible papers, we found several categories of supported tasks. Those are sign detection, text detection, object detection, door detection, traffic light detection, object tracking, and navigation.

We found an eligible r3esearch that help VIP to recognize symbols in toilets, pharmacies, and trains (Dahiya, Issac, Dutta, Říha, \& Kř́iž, 4-6 July 2018), while another studies help2ed VIP to recognize signs-based-text, then the text will be converted into sound (Jiang, Gonnot, Yi, \& Saniie, 14-17 May 2017) (Sivan \& Darsan, 2016). To detect objects, two studies try to help VIP to detect moving and not moving objects in the outdoor area (Mocanu, Tapu, \& Zaharia, 2017) (Joshi, Yadav, Dutta, \& Travieso-Gonzalez, 2020), while another study proposed a system that can detect objects in the indoor area (Sivan \& Darsan, 2016) (Afif, Ayachi, Pissaloux, Said, \& Atri, 2020). Another study helped to assist VIP by detecting surrounding obstacles so that VIP can navigate their own way with the help of audio feedback (Elmannai \& Elleithy, 2018) (Duh, Sung, Chiang,
Chang, \& Chen, 2020).

A research uses robots to help VIP to navigate and detect objects with a camera attached to the robot (Mahmud, Sourave, Islam, Lin, \& Kim, 2020). Another researcher proposed shopping assistants using smart glasses cameras (Zientara, et al., Feb. 2017), a learning medium for visually impaired children by detecting objects around them by giving a description via voice command (Balasuriya, Lokuhettiarachchi, Ranasinghe, Shiwantha, \& Jayawardena, 2017).

There are also two other studies that help VIP to detect doors (Sivan \& Darsan, 2016) (Talebi \& Vafaei, 2018), and another research focus on helping VI to detect the colors of pedestrian signals (Li, Cui, Rizzo, Wong, \& Fang, 2020). The complete summary can be seen in appendix Table 8 .

\section{CONCLUSION}

The included studies are so diverse that it would not be possible to pool the results from them. However, in the majority of studies, positive effects of the use of computer vision for supporting visually impaired people. These effects included: the detection of obstacles, objects, door and text, traffic lights, sign detections and navigation. The results of this systematic review stress that computer vision really have promising potential for persons who are visually impaired. But the biggest challenge for developers now is to increase the speed of time and improve its accuracy, and we expect the future will have a complete package or solution where blind or vision impaired people will get all the solution together (i.e., map, indoor-outdoor navigation, object recognition, obstacle recognition, person recognition, human crowd behavior, crowd human counting, study / reading, entertainment etc.) in one software and in handheld devices like android. We believe that this will happen in the future, and this paper will help the developer to know the very background in broad models.

\section{REFERENCES}

Afif, M., Ayachi, R., Pissaloux, E., Said, Y., \& Atri, M. (2020). Indoor objects detection and recognition for an ICT mobility assistance of visually impaired people. Multimedia Tools and Applications, 79(41), 31645-31662.

Balasuriya, B., Lokuhettiarachchi, N., Ranasinghe, A., Shiwantha, K., \& Jayawardena, C. (2017). Learning platform for visually impaired children through artificial intelligence and computer vision. 11th International Conference on Software, Knowledge, Information Management and Applications (SKIMA).

Dahiya, D., Issac, A., Dutta, M. K., Říha, K., \& Kříž, P. (2018). Computer Vision Technique for Scene Captioning to Provide Assistance to Visually Impaired. 41st International Conference on Tele- 
communications and Signal Processing (TSP).

Duh, P.-J., Sung, Y.-C., Chiang, L.-Y. F., Chang, Y.-J., \& Chen, K.-W. (2020). V-Eye: A Vision-based Navigation System for the Visually Impaired. IEEE Transactions on Multimedia.

Elmannai, W., \& Elleithy, K. M. (2018). Computer Vision-Based Framework for Supporting the Mobility of the Visually Impaired. Bridgeport, CT: University of Bridgeport.

Global Data on Visual Impairments (2010). Geneva, Switzerland: World Health Organization.

Hakobyan, L., Lumsden, J., O’Sullivan, D., \& Bartlett, H. (2013). Mobile assistive technologies for the visually impaired. Survey of Ophthalmology, 58(6), 513-528.

Jiang, H., Gonnot, T., Yi, W.-J., \& Saniie, J. (2017). Computer vision and text recognition for assisting visually impaired people using Android smartphone. IEEE International Conference on Electro Information Technology (EIT).

Joshi, R. C., Yadav, S., Dutta, M. K., \& Travieso-Gonzalez, C. (2020). Efficient Multi-Object Detection and Smart Navigation Using Artificial Intelligence for Visually Impaired People. Entropy, 22(9), 941.

Kitchenham, B. (2004). Procedures for performing systematic reviews. Keele, UK, Keele University, 33(2004), 1-26.

Li, X., Cui, H., Rizzo, J.-R., Wong, E., \& Fang, Y. (2020). ross-Safe: A Computer Vision-Based Approach to Make All Intersection-Related Pedestrian Signals Accessible for the Visually Impaired. Advances in Intelligent Systems and Computing. Cham.

Mahmud, S., Sourave, R. H., Islam, M., Lin, X., \& Kim, J.-H. (2020). A Vision based Voice Controlled Indoor Assistant Robot for Visually Impaired Peopl. IEEE International IOT, Electronics and Mechatronics Conference (IEMTRONICS).

Mocanu, B., Tapu, R., \& Zaharia, T. (2017). Seeing Without Sight - An Automatic Cognition System Dedicated to Blind and Visually Impaired People. International Conference on Computer Vision Workshops (ICCVW).

Shapiro, L., \& Stockman, G. (2001). Computer Vision. Prentice Hall.

Sivan, S., \& Darsan, G. (2016). Computer Vision based Assistive Technology for Blind and Visually Impaired People. Proceedings of the 7th International Conference on Computing Communication and Networking Technologies. Dallas, TX, USA.

Talebi, M., \& Vafaei, A. (2018). Vision-based entrance detection in outdoor scenes. Multimedia Tools and Applications, 77(20), 26219-26238.
Zientara, P., Lee, S., Smith, G., Brenner, R., Itti, L., Rosson, M., . . . Narayanan, V. (2017). Third Eye: A Shopping Assistant for the Visually Impaired. Computer, 50(2), 16-24. 
Table 5. Summary of Research Result

\begin{tabular}{|c|c|c|c|c|c|}
\hline $\begin{array}{l}\text { Research } \\
\text { Number }\end{array}$ & Authors & Title & Algorithms (RQ1) & Devices (RQ2) & $\begin{array}{c}\text { Supported } \\
\text { Tasks (RQ3) }\end{array}$ \\
\hline $\begin{array}{c}\text { RS1 (Jiang, } \\
\text { Gonnot, Yi, \& } \\
\text { Saniie, 14-17 May } \\
\text { 2017) }\end{array}$ & $\begin{array}{l}\text { Hao Jiang, Thomas } \\
\text { Gonnot, Won-Jae Yi } \\
\text { and Jafar Saniie }\end{array}$ & $\begin{array}{l}\text { Computer vision and text } \\
\text { recognition for assisting } \\
\text { visually impaired } \\
\text { people using Android } \\
\text { smartphone }\end{array}$ & $\begin{array}{c}\text { Character } \\
\text { Recognition: } \\
\text { Optical Character } \\
\text { Recognition }\end{array}$ & $\begin{array}{l}\text { Mobile Phone: } \\
\text { Google Nexus } \\
\text { 5X phone, } \\
\text { running } \\
\text { Android } 6.0\end{array}$ & $\begin{array}{c}\text { Text } \\
\text { Reading, } \\
\text { Object// } \\
\text { Obstacle } \\
\text { Detection }\end{array}$ \\
\hline $\begin{array}{l}\text { RS2 (Sivan \& } \\
\text { Darsan, 2016) }\end{array}$ & $\begin{array}{l}\text { Shankar Sivan and } \\
\text { Gopu Darsan }\end{array}$ & $\begin{array}{l}\text { Computer Vision based } \\
\text { Assistive Technology } \\
\text { For Blind and Visually } \\
\text { Impaired People }\end{array}$ & $\begin{array}{l}\text { Edge Detection: } \\
\text { Canny Edge } \\
\text { Detector; } \\
\text { Character } \\
\text { Recognition: } \\
\text { Optical Character } \\
\text { Recognition; } \\
\text { Feature Extraction: } \\
\text { BRISK }\end{array}$ & $\begin{array}{l}\text { Single Board: } \\
\text { Raspberry } \\
\text { Pi } 3 \text { Model } \\
\text { B; Camera: } \\
\text { Logitech C310 } \\
\text { webcam } 5 \\
\text { mega-pixels }\end{array}$ & $\begin{array}{c}\text { Text } \\
\text { Reading, } \\
\text { Object/ } \\
\text { Obstacle } \\
\text { Detection, } \\
\text { Door } \\
\text { Detection }\end{array}$ \\
\hline $\begin{array}{c}\text { RS3 (Dahiya, } \\
\text { Issac, Dutta, Ŕíha, } \\
\text { \& Kř́ž, 4-6 July } \\
\text { 2018) }\end{array}$ & $\begin{array}{c}\text { Dhruv Dahiya, } \\
\text { Ashish Issac, Malay } \\
\text { Kishore Dutta, } \\
\text { Kamil Říha, Petr } \\
\text { Kř́̌ž }\end{array}$ & $\begin{array}{c}\text { Computer Vision } \\
\text { Technique for Scene } \\
\text { Captioning to Provide } \\
\text { Assistance to Visually } \\
\text { Impaired }\end{array}$ & $\begin{array}{c}\text { Feature Extraction: } \\
\text { SURF }\end{array}$ & $\begin{array}{l}\text { Computer: } \\
\text { CPU 1.8 GHz, } \\
\text { 8GB RAM, } \\
\text { 64bit }\end{array}$ & $\begin{array}{c}\text { Sign } \\
\text { Detection }\end{array}$ \\
\hline $\begin{array}{l}\text { RS4 (Li, Cui, } \\
\text { Rizzo, Wong, \& } \\
\text { Fang, 2020) }\end{array}$ & $\begin{array}{l}\text { Xiang Li, Hanzhang } \\
\text { Cui, John-Ross } \\
\text { Rizzo, Edward } \\
\text { Wong, and Yi Fang }\end{array}$ & $\begin{array}{l}\text { Cross-Safe: A Computer } \\
\text { Vision-Based Approach } \\
\text { to Make All Intersection- } \\
\text { Related Pedestrian } \\
\text { Signals Accessible for } \\
\text { the Visually Impaired }\end{array}$ & $\begin{array}{l}\text { Object/Obstacle } \\
\text { Detection: CNN; }\end{array}$ & $\begin{array}{c}\text { Single Board: } \\
\text { NVDIA Jetson } \\
\text { TX2 } 256 \\
\text { CUDA cores; } \\
\text { Camera: Zed } \\
\text { Camera 1080p } \\
\text { HD video } \\
\text { at 30FPS or } \\
\text { WVGA at } \\
\text { 100FPS. }\end{array}$ & $\begin{array}{l}\text { Traffic Light } \\
\text { Detection }\end{array}$ \\
\hline $\begin{array}{l}\text { RS5 (Mocanu, } \\
\text { Tapu, \& Zaharia, } \\
\text { 2017) }\end{array}$ & $\begin{array}{l}\text { Bogdan Mocanu, } \\
\text { Ruxandra Tapu, and } \\
\text { Titus Zaharia }\end{array}$ & $\begin{array}{l}\text { Seeing without sight - } \\
\text { An automatic cognition } \\
\text { system dedicated to } \\
\text { blind and visually } \\
\text { impaired people }\end{array}$ & $\begin{array}{l}\text { Object/Obstacle } \\
\text { Detection: } \\
\text { YOLOv1; }\end{array}$ & $\begin{array}{c}\text { Computer: } \\
\text { Ultra book } \\
\text { laptop and } \\
\text { NVDIA GTX } \\
1050\end{array}$ & $\begin{array}{l}\text { Object } \\
\text { Tracking, } \\
\text { Object/ } \\
\text { Obstacle } \\
\text { Detection }\end{array}$ \\
\hline
\end{tabular}

\begin{tabular}{|c|c|c|c|c|c|}
\hline $\begin{array}{c}\text { RS6 (Afif, Ayachi, } \\
\text { Pissaloux, Said, \& } \\
\text { Atri, 2020) }\end{array}$ & $\begin{array}{l}\text { Mouna Afif, Riadh } \\
\text { Ayachi, Edwige } \\
\text { Pissaloux, Yahia } \\
\text { Said, and Mohamed } \\
\text { Atri }\end{array}$ & $\begin{array}{l}\text { Indoor objects detection } \\
\text { and recognition for an } \\
\text { ICT } \\
\text { mobility assistance of } \\
\text { visually impaired people }\end{array}$ & $\begin{array}{l}\text { Object/Obstacle } \\
\text { Detection: } \\
\text { YOLOv3 }\end{array}$ & $\begin{array}{l}\text { Computer: } \\
\text { Intel Xeon } \\
\text { E5-2683 v4 } \\
\text { Processor; } \\
\text { NVDIA } \\
\text { Quadro M4000 } \\
\text { GPU }\end{array}$ & $\begin{array}{c}\text { Object/ } \\
\text { Obstacle } \\
\text { Detection }\end{array}$ \\
\hline $\begin{array}{c}\text { RS7 (Joshi, Yadav, } \\
\text { Dutta, \& Travieso- } \\
\text { Gonzalez, 2020) }\end{array}$ & $\begin{array}{c}\text { Rakesh Chandra } \\
\text { Joshi, Saumya } \\
\text { Yadav, Malay } \\
\text { Kishore Dutta and } \\
\text { Carlos M. Travieso- } \\
\text { Gonzalez }\end{array}$ & $\begin{array}{c}\text { Efficient Multi-Object } \\
\text { Detection and Smart } \\
\text { Navigation Using } \\
\text { Artificial Intelligence } \\
\text { for Visually Impaired } \\
\text { People }\end{array}$ & $\begin{array}{l}\text { Object/Obstacle } \\
\text { Detection: } \\
\text { YOLOv3; } \\
\text { Character } \\
\text { Recognition: } \\
\text { Optical Character } \\
\text { Recognition }\end{array}$ & $\begin{array}{c}\text { Single Board: } \\
\text { DSP processor } \\
\text { 64-bit, quad- } \\
\text { core, and } 1.5 \\
\text { GHz, } 4 \text { GB } \\
\text { SDRAM; } \\
\text { Camera: } 8 \mathrm{MP} \\
\text { Camera }\end{array}$ & $\begin{array}{c}\text { Text } \\
\text { Recognition, } \\
\text { Object/ } \\
\text { Obstacle } \\
\text { Detection }\end{array}$ \\
\hline $\begin{array}{l}\text { RS8 (Duh, Sung, } \\
\text { Chiang, Chang, \& } \\
\text { Chen, 2020) }\end{array}$ & $\begin{array}{l}\text { Ping-Jung Duh, Yu- } \\
\text { Cheng Sung, Liang- } \\
\text { Yu Fan Chiang, } \\
\text { Yung-Ju Chang, and } \\
\text { Kuan-Wen Chen }\end{array}$ & $\begin{array}{l}\text { V-Eye: A Vision-based } \\
\text { Navigation System for } \\
\text { the Visually Impaired }\end{array}$ & $\begin{array}{c}\text { Feautre Extraction: } \\
\text { ORB; Image } \\
\text { Segmentation: } \\
\text { FRRN }\end{array}$ & $\begin{array}{c}\text { Computer: } \\
\text { Intel Core } \\
\text { i7-6700HQ } \\
\text { (8 cores @ } \\
\text { 2.40GHz) and } \\
\text { 16GB RAM; } \\
\text { Camera: } \\
\text { GoPro5 }\end{array}$ & Navigation \\
\hline
\end{tabular}




\begin{tabular}{|c|c|c|c|c|c|}
\hline $\begin{array}{l}\text { RS9 (Talebi \& } \\
\text { Vafaei, 2018) }\end{array}$ & $\begin{array}{l}\text { Mehdi Talebi, } \\
\text { Abbas Vafaei, } \\
\text { and Amirhassan } \\
\text { Monadjemi }\end{array}$ & $\begin{array}{l}\text { Vision-based entrance } \\
\text { detection in outdoor } \\
\text { scenes }\end{array}$ & $\begin{array}{l}\text { Edge Detection: } \\
\text { Line Segment } \\
\text { Detector }\end{array}$ & $\begin{array}{l}\text { Computer: } \\
\text { Intel Core i7 } \\
2.1 \mathrm{GHz}\end{array}$ & $\begin{array}{c}\text { Door } \\
\text { Detection }\end{array}$ \\
\hline $\begin{array}{l}\text { RS10 (Elmannai } \\
\text { \& Elleithy, 2018) }\end{array}$ & $\begin{array}{c}\text { Wafa M. Elmannai, } \\
\text { and Khaled M. } \\
\text { Elleithy }\end{array}$ & $\begin{array}{l}\text { A Novel Obstacle } \\
\text { Avoidance System for } \\
\text { Guiding the Visually } \\
\text { Impaired through the use } \\
\text { of Fuzzy Control Logic }\end{array}$ & $\begin{array}{c}\text { Image } \\
\text { Classification: } \\
\text { KNN; Image } \\
\text { Segmentation: } \\
\text { K-Means } \\
\text { Clustering; Feature } \\
\text { Extraction: ORB }\end{array}$ & $\begin{array}{l}\text { Single Board: } \\
\text { FEZ Spider; } \\
\text { Camera: L2 } \\
\text { Module }\end{array}$ & $\begin{array}{c}\text { Navigation, } \\
\text { Object/ } \\
\text { Obstacle } \\
\text { Detection }\end{array}$ \\
\hline $\begin{array}{l}\text { RS11 (Mahmud, } \\
\text { Sourave, Islam, } \\
\text { Lin, \& Kim, 2020) }\end{array}$ & $\begin{array}{l}\text { Saifuddin Mahmud, } \\
\text { Redwanul Haque } \\
\text { Sourave, Md. Milon } \\
\text { Islam, Xiangxu Lin, } \\
\text { and Jong-Hoon Kim }\end{array}$ & $\begin{array}{l}\text { A Vision based Voice } \\
\text { Controlled Indoor } \\
\text { Assistant Robot for } \\
\text { Visually Impaired People }\end{array}$ & $\begin{array}{l}\text { Object/Obstacle } \\
\text { Detection: } \\
\text { YOLOv3; Feature } \\
\text { Extraction: SURF }\end{array}$ & $\begin{array}{c}\text { Robot: TeleBot } \\
\text { R2; Camera: } \\
\text { 4K Camera, } \\
\text { Astra S } \\
\text { Camera } \\
\end{array}$ & $\begin{array}{c}\text { Object/ } \\
\text { Obstacle } \\
\text { Detection }\end{array}$ \\
\hline $\begin{array}{l}\text { RS12 (Zientara, et } \\
\text { al., Feb. 2017) }\end{array}$ & $\begin{array}{l}\text { Peter A. Zientara, } \\
\text { Sooyeon Lee, and } \\
\text { Gus H. Smith, Rorry } \\
\text { Brenner, Laurent } \\
\text { Itti, Mary B. Rosson } \\
\text {, John M. Carroll, } \\
\text { Kevin M. Irick, } \\
\text { and Vijaykrishnan } \\
\text { Narayanan }\end{array}$ & $\begin{array}{l}\text { Third Eye: } \\
\text { A Shopping Assistant } \\
\text { for the Visually Impaired }\end{array}$ & $\begin{array}{c}\text { Image } \\
\text { Classification: } \\
\text { SVM; Feature } \\
\text { Extraction: SURF }\end{array}$ & $\begin{array}{c}\text { Computer: } \\
\text { IBM POWER8 } \\
160 \text { cores } \\
3.6 \mathrm{GHz} ; \\
\text { NVIDIA } \\
\text { GPU K1200; } \\
\text { Camera: Smart } \\
\text { Glass Camera }\end{array}$ & $\begin{array}{c}\text { Object/ } \\
\text { Obstacle } \\
\text { Detection }\end{array}$ \\
\hline $\begin{array}{l}\text { RS13 (Balasuriya, } \\
\text { Lokuhettiarachchi, } \\
\text { Ranasinghe, } \\
\text { Shiwantha, \& } \\
\text { Jayawardena, } \\
\text { 2017) }\end{array}$ & $\begin{array}{l}\text { B. K. Balasuriya, N. } \\
\text { P. Lokuhettiarachchi, } \\
\text { A. R. M. D. N. } \\
\text { Ranasinghe, K. D. } \\
\text { C. Shiwantha, and C. } \\
\text { Jayawardena }\end{array}$ & $\begin{array}{l}\text { Learning Platform } \\
\text { for Visually Impaired } \\
\text { Children through } \\
\text { Artificial Intelligence } \\
\text { and Computer Vision }\end{array}$ & $\begin{array}{l}\text { Object/Obstacle } \\
\text { Detection: CNN; }\end{array}$ & Not Mentioned & $\begin{array}{c}\text { Object/ } \\
\text { Obstacle } \\
\text { Detection }\end{array}$ \\
\hline
\end{tabular}

Table 6. Algorithm Used

\begin{tabular}{|c|c|c|}
\hline Used in & Algorithms & Research Number \\
\hline \multirow[t]{2}{*}{ Edge Detection } & Canny Edge Detector & RS2 (Sivan \& Darsan, 2016), \\
\hline & Line Segment Detector & RS9 (Talebi \& Vafaei, 2018) \\
\hline \multirow{3}{*}{$\begin{array}{l}\text { Objects/Obstacle } \\
\text { Detection }\end{array}$} & $\mathrm{CNN}$ & RS4 (Li, Cui, Rizzo, Wong, \& Fang, 2020) \\
\hline & YOLO & RS5 (Mocanu, Tapu, \& Zaharia, 2017) \\
\hline & YOLOv3 & $\begin{array}{l}\text { RS6 (Afif, Ayachi, Pissaloux, Said, \& Atri, 2020), RS7 (Joshi, } \\
\text { Yadav, Dutta, \& Travieso-Gonzalez, 2020), RS11 (Mahmud, } \\
\text { Sourave, Islam, Lin, \& Kim, 2020) }\end{array}$ \\
\hline \multirow[t]{2}{*}{ Image Classification } & $\mathrm{KNN}$ & RS10 (Elmannai \& Elleithy, 2018) \\
\hline & SVM & RS12 (Zientara, et al., Feb. 2017) \\
\hline \multirow[t]{2}{*}{ Image Segmentation } & K-Means Clustering & RS10 (Elmannai \& Elleithy, 2018) \\
\hline & FRRN & RS8 (Duh, Sung, Chiang, Chang, \& Chen, 2020) \\
\hline Character Recognition & Optical Character Recognition & $\begin{array}{c}\text { RS1 (Jiang, Gonnot, Yi, \& Saniie, 14-17 May 2017), RS2 } \\
\text { (Sivan \& Darsan, 2016), RS7 (Joshi, Yadav, Dutta, \& Travieso- } \\
\text { Gonzalez, 2020) }\end{array}$ \\
\hline \multirow[t]{3}{*}{ Feature Extraction } & BRISK & RS2 (Sivan \& Darsan, 2016) \\
\hline & SURF & $\begin{array}{l}\text { RS3 (Dahiya, Issac, Dutta, Říha, \& Kříž, 4-6 July 2018), RS11 } \\
\text { (Mahmud, Sourave, Islam, Lin, \& Kim, 2020), RS12 (Zientara, } \\
\text { et al., Feb. 2017) }\end{array}$ \\
\hline & ORB & $\begin{array}{l}\text { RS8 (Duh, Sung, Chiang, Chang, \& Chen, 2020), RS10 } \\
\text { (Elmannai \& Elleithy, 2018) }\end{array}$ \\
\hline
\end{tabular}


Table 7. Devices Used

\begin{tabular}{|c|c|c|}
\hline \multicolumn{2}{|r|}{ Devices Used } & Research Number \\
\hline Mobile Phone & $\begin{array}{c}\text { Google Nexus 5X phone, running } \\
\text { Android } 6.0\end{array}$ & RS1 (Jiang, Gonnot, Yi, \& Saniie, 14-17 May 2017) \\
\hline \multirow{4}{*}{$\begin{array}{l}\text { Single Board } \\
\text { Computer }\end{array}$} & Raspberry Pi 3 Model B & RS2 (Sivan \& Darsan, 2016) \\
\hline & $\begin{array}{c}\text { DSP processor 64-bit, quad-core, and } \\
1.5 \mathrm{GHz}, 4 \mathrm{~GB} \text { SDRAM }\end{array}$ & RS7 (Joshi, Yadav, Dutta, \& Travieso-Gonzalez, 2020) \\
\hline & FEZ Spider & RS10 (Elmannai \& Elleithy, 2018) \\
\hline & NVDIA Jetson TX2 256 CUDA cores & RS4 (Li, Cui, Rizzo, Wong, \& Fang, 2020) \\
\hline \multirow[t]{8}{*}{ Camera } & Logitech C310 webcam 5 mega-pixels & RS2 (Sivan \& Darsan, 2016) \\
\hline & $\begin{array}{l}\text { Zed Camera 1080p HD video at 30FPS } \\
\text { or WVGA at 100FPS. }\end{array}$ & RS4 (Li, Cui, Rizzo, Wong, \& Fang, 2020) \\
\hline & 8 MP Camera & RS7 (Joshi, Yadav, Dutta, \& Travieso-Gonzalez, 2020) \\
\hline & GoPro5 & RS8 (Duh, Sung, Chiang, Chang, \& Chen, 2020) \\
\hline & Astra S Camera & RS11 (Mahmud, Sourave, Islam, Lin, \& Kim, 2020) \\
\hline & Smart-glass camera & RS12 (Zientara, et al., Feb. 2017) \\
\hline & 4K Camera & RS11 (Mahmud, Sourave, Islam, Lin, \& Kim, 2020) \\
\hline & L2 Module & RS10 (Elmannai \& Elleithy, 2018) \\
\hline \multirow[t]{6}{*}{ Computer } & CPU $1.8 \mathrm{GHz}, 8 \mathrm{~GB}$ RAM, 64bit & RS3 (Dahiya, Issac, Dutta, Říha, \& Kříž, 4-6 July 2018) \\
\hline & NVDIA GTX 1050 & RS5 (Mocanu, Tapu, \& Zaharia, 2017) \\
\hline & $\begin{array}{l}\text { Intel Xeon E5-2683 v4 Processor; } \\
\text { NVDIA Quadro M4000 GPU }\end{array}$ & RS6 (Afif, Ayachi, Pissaloux, Said, \& Atri, 2020) \\
\hline & $\begin{array}{c}\text { Intel Core i7-6700HQ (8 cores @ } \\
2.40 \mathrm{GHz} \text { ) and 16GB RAM }\end{array}$ & RS8 (Duh, Sung, Chiang, Chang, \& Chen, 2020) \\
\hline & Intel Core i7 $2.1 \mathrm{GHz}$ & RS9 (Talebi \& Vafaei, 2018) \\
\hline & $\begin{array}{l}\text { IBM POWER8 } 160 \text { cores } 3.6 \mathrm{GHz} \text {; } \\
\text { NVIDIA GPU K1200 }\end{array}$ & RS12 (Zientara, et al., Feb. 2017) \\
\hline Robot & TeleBot-R2 & RS11 (Mahmud, Sourave, Islam, Lin, \& Kim, 2020) \\
\hline \multicolumn{3}{|c|}{ Table 8. Supported Tasks } \\
\hline \multicolumn{2}{|c|}{ Supported Tasks } & Research Number \\
\hline \multicolumn{2}{|c|}{ Sign Detection } & $\begin{array}{l}\text { 14-17 May 2017), RS3 (Dahiya, Issac, Dutta, Ř́iha, \& Kř́̌ž, } \\
\text { 2018), RS2 (Sivan \& Darsan, 2016) }\end{array}$ \\
\hline \multicolumn{2}{|c|}{ Text Detection } & Saniie, 14-17 May 2017), RS2 (Sivan \& Darsan, 2016) \\
\hline \multicolumn{2}{|r|}{$\begin{array}{l}\text { RS5 (Mocanu, Tapu, \& Z } \\
\text { RS7 (Joshi, Yadav, Dutta, } \\
\text { Chen, 2020), RS10 (Elmann }\end{array}$} & $\begin{array}{l}\text {, 2017), RS6 (Afif, Ayachi, Pissaloux, Said, \& Atri, 2020), } \\
\text { vieso-Gonzalez, 2020), RS8 (Duh, Sung, Chiang, Chang, \& } \\
\text { Elleithy, 2018), RS11 (Mahmud, Sourave, Islam, Lin, \& Kim, } \\
\text { b. 2017), RS13 (Balasuriya, Lokuhettiarachchi, Ranasinghe, } \\
\text { wantha, \& Jayawardena, 2017) }\end{array}$ \\
\hline \multicolumn{2}{|c|}{ Door Detection } & Darsan, 2016), RS9 (Talebi \& Vafaei, 2018) \\
\hline \multicolumn{2}{|c|}{ Traffic Light Detection } & i, Cui, Rizzo, Wong, \& Fang, 2020) \\
\hline \multicolumn{2}{|c|}{ Object Tracking } & Mocanu, Tapu, \& Zaharia, 2017) \\
\hline Navigation & RS8 (Duh, Sung, Chiang, & $\begin{array}{l}\text { g, \& Chen, 2020), RS11 (Mahmud, Sourave, Islam, Lin, \& } \\
\text { Kim, 2020) }\end{array}$ \\
\hline
\end{tabular}

